\title{
Awareness of Rural Couples About Sex-Ratio
}

\author{
Esther, A. Ghosh ${ }^{1}$, Rita Goel ${ }^{1}$ and Shanti Balda ${ }^{2}$ \\ ${ }^{1}$ Department of Home Science Extension Education and ${ }^{2}$ Department of Human Development \\ and Family Studies, CCS Haryana Agricultural University, Hisar 125004, Haryana, India
}

KEYWORDS Sex Ratio. Awareness. Gender. Female Foeticide

\begin{abstract}
There is growing imbalance in the male-female ratio. Sex-ratio is a three tier phenomenon. First, it means the number of females per 1000 males in respect to the total population. Secondly, sex-ratio at birth indicates the number of female children born per 1000 males children. Thirdly sex-ratio in the lowest age group among children from birth to six years. As per 2001 census, the overall sex-ratio of India is 933 females per 1000 males which is less than the overall international sex-ratio of 986 females per 1000 males. Hence it was thought relevant to study awareness of rural couples on these issues. The study was conducted by selecting two villages Palpur and Ravanika from two blocks of district Allahabad from Uttar Pradesh by random selection. From each village a sample of 50 couples under the age of 45 years were randomly selected to make a total sample size of 100 couples. Awareness about sex-ratio, quite a large number of males (64\%) and females (74\%) had no knowledge about it. Females foeticide was cited by respondents (41\% male and $36 \%$ females) as the main reasons for the imbalanced sex-ratio. Eighty one per cent males and 65 per cent females felt that the major problem due to imbalanced sex-ratio would be non-availability of brides.
\end{abstract}

\section{INTRODUCTION}

If we look at the sex-ratio in the census results, there is growing imbalance in the malefemale ratio. Sex-ratio is a three tier phenomenon. First, it means the number of females per 1000 males in respect to the total population. Secondly, sex-ratio at birth indicates the number of female children born per 1000 males children. Thirdly, sex-ratio in the lowest age group among children from birth to six years. As per 2001 census, the overall sex ratio of India is 933 females per 1000 males which is less than the overall international sex-ratio of 986 females per 1000 males (Census, 2001). Several reasons have been accounted for the low levels of sex-ratio such as the neglect of girl child resulting in high mortality at young age, male migration and female infanticide and sex selective female abortion etc. Hence it was thought relevant to study awareness of rural couples on this issue.

\section{METHODOLOGY}

The study was conducted by selecting Allahabad district of Uttar Pradesh purposively. Two blocks Chaka and Karchana were randomly selected. Of these two blocks, one village each, i.e. Palpur from Chaka block and Ravanika village of Karchana block were randomly selected. From each village a sample of 50 couples under the age of 45 years was also randomly selected. Thus, the total sample size was of 100 couples

\section{RESULTS AND DISCUSSION}

Table 1 reveals that about sex-ratio, quite a large number of males (64\%) and females (74\%) had no knowledge above it, while 35 per cent males and 20 per cent females had low knowledge about it. There were none in the high knowledge level.

According to Table 2, female foeticide was cited by respondents (41\% males and $36 \%$ females) as the main reason for the imbalanced sex ratio. Only 7 per cent males stated dowry

Table 1: General awareness about sex-ratio $(\mathbf{N}=\mathbf{2 0 0})$

\begin{tabular}{llrr}
\hline S.No. & Knowledge level & Male & Female \\
\hline 1. & Nil (0) & $64(64.0)$ & $79(79.0)$ \\
2. & Low (1-3) & $35(35.0)$ & $20(20.0)$ \\
3. & Medium (4-6) & $1(1.0)$ & $1(1.0)$ \\
4. & High (7-9) & - & - \\
\hline
\end{tabular}

Figures in parentheses denote percentages

Table 2: Reasons for imbalanced sex-ratio $(\mathbf{N}=\mathbf{2 0 0})$

\begin{tabular}{llcc}
\hline S. No. & Reasons & Male & Female \\
\hline 1. & $\begin{array}{l}\text { Neglect of girl child } \\
\text { resulting in higher } \\
\text { female mortality }\end{array}$ & $1 \quad(1.0)$ & - \\
2. & Maternal death & - & - \\
3. & Dowry death & $7(7.0)$ & - \\
4. & Female infanticide & - & - \\
5. & Female foeticide & $41(41.0)$ & $36(36.0)$ \\
6. & Male migration & - & -
\end{tabular}

Multiple response table

Figures in parentheses denote percentages 
Table 3: Problems caused by imbalanced sex-ratio ( $N=200)$

\begin{tabular}{llcc}
\hline S.No. & Problems & Male & Female \\
\hline 1. & $\begin{array}{l}\text { Non-availability } \\
\text { of brides }\end{array}$ & $81(81.0)$ & $65(65.0)$ \\
2. & $\begin{array}{l}\text { Rise in sexual } \\
\text { violence against }\end{array}$ & $5(5.0)$ & $5 \quad(5.0)$ \\
women & $\begin{array}{l}\text { Lack of female } \\
\text { workforce }\end{array}$ & $5(5.0)$ & $2 \quad(2.0)$ \\
4. & Polyandry & $2(2.0)$ & $4 \quad(4.0)$ \\
\hline
\end{tabular}

Multiple response table

Figures in parentheses denote percentages

deaths resulting in higher female mortality as one of the reasons. Their awareness about other reasons was nil. Bose et al. (2002) estimated that about 5 per cent of female foetus in India are aborted among women who have these tests. In Haryana it is estimated that 43 per cent of the female foetuses are likely to have been aborted for these same women.

It is clear from Table 3 that 81 per cent males and 65 per cent females felt that the major problem due to imbalanced sex-ratio would be the non availability. A few percentage of males and females also stated that crime against women would increase it would lesser the female work force and give rise to polyandry. According to Dubey (2001) societies which have an adverse female sex-ratio can develop customs like polyandry, as well as increased rape and prostitution.

\section{REFERENCES}

Bose. Ashish, Arnold, Fred and Roy, T.K.: Curbing female foeticide. Economic and Political Weekly, 37(8): 696697 (2002).

Census of India. 2001. http://www.censusindia.net.

Dubey, Lela (2001) Cited by Rao, Radhakrishan: Stop foeticide. Social Welfare, 48 (8): 27 (2001). 